\title{
¿Qué fue el budismo mahāyāna?
}

\author{
Juan ARNAU \\ Consejo Superior de Investigaciones Científicas, CSIC \\ juan.arnau@uv.es, arnaujuan@gmail.com
}

\section{RESUMEN}

A principios de nuestra era se inicia en el budismo indio un nuevo género literario dentro de la propia comunidad monástica. Esta nueva literatura, que se reivindica como buddhavacana («palabra de Buda»), se produce en minorías desperdigadas a lo largo de la geografía india y en un contexto monástico y se denomina a sí misma mahāyāna. En ella se resalta la figura del bodhisattva como ideal supremo. En el siglo II o III, Nāgārjuna equipara saṁsāra y nirvana, elevando esta literatura, mayoritariamente devocional, a rango filosófico. El nirvana deja de ser el lugar central para dar paso a una determinada actitud filosófica: el discernimiento de la vacuidad, y a una determinada actitud altruista: la identificación afectiva y solidaria con aquellos que sufren. Los dos ejes de la vida del bodhisattva.

Palabras clave: Mahāyāna, Orígenes del mahāyāna, Filosofía budista, bodhisattva.

\section{What was mahāyana Buddhism?}

\begin{abstract}
In the beginning of the Common Era, in the context of the Buddhist monastic community takes place a new genre of literature, considered itself as Buddhavacana (the «Word of the Buddha»). It arises in different places in the Buddhist community and very spread around the geography of India, and it is considered itself as Mahāyāna. This new genre stresses the figure of the bodhisattva as the supreme ideal. After the work of Buddhist philosopher Nāgārjuna, in the second or third century of the Common Era, the concept of nirvana is no more the centre of the Buddhist cult and speculation, yielding a new ideal: the discernment of emptiness and the compassion to those who suffer. These two become the axis around spins the life of the bodhisattva.
\end{abstract}

Keywords: Mahāyāna, Origins of the Mahāyāna, Buddhist Philosophy, bodhisattva.

SUMARIO: 1. Historias del mahāyāna. 2. El desarrollo filosófico del mahāyāna. 3. Conclusiones. 


\section{HISTORIAS DEL MAHĀYĀNA}

Según el relato del Mahāparinirvāṇa sūtra de la escuela sarvāstivāda, en los últimos días de su vida, Siddhārta Gautama, el Buda, dijo gentilmente a su fiel înanda:

Desde un principio os he enseñado que cualquier cosa, por encantadora y grata que sea, se encuentra sujeta a la descomposición y desintegración. Así pues, înanda, ya sea ahora o tras mi muerte, dondequiera que estéis, debéis permanecer como islas, recogidos en vosotros mismos y protegidos por el dharma, indiferentes a otras islas y otros resguardos. Si me preguntas por qué digo esto, te diré que aquellos que, ahora o tras mi muerte, se mantengan recogidos en el dharma, protegidos por el dharma, indiferentes a las defensas de los demás, esos serán mis más destacados discípulos. ${ }^{1}$

Cuando el maestro muere alrededor del año 482 antes de nuestra era (o quizá en el año 370), pide a sus discípulos que hagan de la enseñanza su única guía y declina nombrar un sucesor. Este hecho y la falta de una estructura jerárquica dentro de la comunidad, marcará el desarrollo ulterior del budismo. Ello no quiere decir que no hubiera discípulos destacados o con el prestigio suficiente como para asumir la organización de la sañgha. De hecho, en el canon pāli encontramos referencias a Sāriputra como experto en el análisis doctrinal y a Upāli como experto en el código monástico (vinaya). Según la tradición, inmediatamente después de la muerte del fundador se celebró el concilio de Rājagṛha para fijar el canon de textos recordados y dilucidar la naturaleza y extensión del dharma. Al tratarse de una tradición oral, el trabajo de recitación y conservación de los textos se repartió entre aquellos dedicados a la memorización de los diálogos (sūtra) y aquellos encargados de la memorización de las reglas monásticas (vinaya). Pero lo que emergió de estos concilios, más que la unificación de las enseñanzas, fue una diversificación de éstas. En los años que siguieron se formarían diversas comunidades de monjes que se identificaban a sí mismas como budistas, todas mantuvieron las viejas costumbres: mendigaban la comida en las aldeas y llevaban una vida itinerante, estableciendo únicamente campamentos en la época de lluvias. Cada una de ellas tenía su propio código de conducta y preservaba sus propios textos. Con su crecimiento y dispersión, las transformaciones serían inevitables. Con el paso del tiempo, algunas de estas comunidades se reunirían periódicamente para celebrar concilios (samgiti, literalmente, recitar al unísono). De ellos surgieron las denominadas dieciocho escuelas del budismo temprano. Dada la frugalidad de la vida que llevaban, no se han conservado apenas registros de este periodo, ya sea en forma de documentos, inscripciones o restos arqueológicos. Las fuentes documentales: textos doctrinales, crónicas, doxografías, hagiografías, listas de maestros o escuelas, registros de traductores, o diarios de peregrinos chinos que recorrieron la

Citado y traducido del tibetano por D. L. Snellgrove en su artículo «Śākyamuni's Final Nivāna», BSOAS 36/2 (1973), pp. 401-2. 
India, son muy posteriores al momento de aparición de estas escuelas. Al parecer, la primera escisión registrada se produjo entre aquellos pertenecientes a la gran comunidad, los mahāsamighika, y los denominados «antiguos»: sthavira. Al primer grupo pertenecería la escuela lokottaravāda, al segundo el theravāda. Otras escuelas de influencia en el norte fueron los sarvāstivāda (vaibhāṣika) y los sautrantika. No todas ellas dieron a los tratados de síntesis de la doctrina, denominada abhidharma, un estatus canónico, aunque sí lo hicieron estas dos últimas. De entre todas las doctrinas de estas dieciocho escuelas, nos interesará especialmente aquí aquella que sostenía la naturaleza supramundana (lokottara) del Buda histórico. Conviene recordar que los primeros textos que pueden considerarse mahāyāna, los sūtra de la prajñāpāramitā, mostraban en general cierta indiferencia hacia las disquisiciones doctrinales y los tecnicismos del abhidharma, mientras que expresaban cierta afinidad con algunas de las ideas que probablemente fueron desarrolladas por la escuela lokottaravāda de los mahāsamghika.

Estos procesos históricos de diversificación de la doctrina, que a primera vista podrían parecer fenómenos distorsionadores de una enseñanza original, sirvieron para constatar los diferentes niveles de lectura que destilaban los textos preservados por las diversas tradiciones. Dentro de esa corriente de pensamiento que llamamos mahāyāna, dicha versatilidad y adaptabilidad se considera una de las grandes virtudes del dharma: la enseñanza se adapta a los oídos de aquellos que necesitan escucharla y ese efecto es resultado de la identificación afectiva de los budas con los seres que sufren. Como veremos a continuación, el énfasis mahāyāna en la erradicación del sufrimiento, denominado con el nombre técnico de karuṇa , tendrá como resultado una concepción pragmática de la verdad, siendo el valor de la enseñanza el beneficio que ésta pudiera reportar a los seres. La clásica metáfora de Buda como médico, cuya doctrina es remedio de efectos saludables, tomará aquí el lugar central. Y la intención, el voto del bodhisatt$v a$ : su compromiso de alcanzar el despertar para beneficio de todos los seres, denominado técnicamente bodhicitta, pasará a considerarse superior a cualquier precepto, cualquier restricción causal o cualquier objetivo soteriológico (i.e. el nirvana).

Si bien las tradiciones no mahāyāna reconocían la figura del bodhisattva, que acrecienta su sabiduría y bondad a lo largo de numerosas existencias hasta alcanzar el despertar supremo, su ideal era el arhat (pāli, arahant), «el que se lo merece», aquel que buscaba denodadamente la liberación y no regresaba al mundo. Con el nuevo énfasis en la empatía y la solidaridad hacia los seres que sufren, el bodhisattva, superior moralmente al arhat, se queda en el mundo y no entra en el nirvana hasta no haber rescatado al más insignificante de los seres vivos. Ello le lleva a renacer una y otra vez, en los lugares más insospechados, con el propósito de rescatar a los seres que, cegados por su codicia y resentimiento, vagan sin rumbo por los diferentes ámbitos de existencia. La doctrina ya no es una vía de escape sino un compromiso con todas las formas de vida.

Desde la perspectiva histórica, las doctrinas budistas experimentarían además la influencia de otras tradiciones de pensamiento en el proceso mismo de su difusión, sirviendo tanto de elemento «civilizador» de tribus de nómadas, como en el caso de 
Asia Central, como de elementos de estructuración y refinamiento de tradiciones de pensamiento más desarrolladas, como en el caso de China.

Pocas cosas pueden afirmarse con seguridad sobre el mahāyāna (Schopen), sus orígenes permanecen todavía oscuros (Williams). Y sin embargo, los historiadores del budismo nos han dejado historias muy diversas acerca del llamado «gran vehículo». Vehículo porque, según la tradición, del mismo modo que la sal es el único sabor del mar, el único sabor del dharma (la doctrina) es el sabor de la liberación (mukti), siendo el budismo mismo el vehículo (yāna) que habrá de recorrer el camino (mārga) hacia ella.

La primera de las historias del mahāyāna que me gustaría mencionar, hoy un tanto desacreditada, fue propuesta por el que quizá haya sido el gran historiador del budismo del siglo XX, Louis de la Vallée Poussin, y sería posteriormente desarrollada por su discípulo Étienne Lamotte (1958). Para estos dos grandes estudiosos la emergencia del mahāyāna supuso el cumplimiento de las aspiraciones del laicismo budista. Un especie de revuelta de los laicos contra la arrogancia y presunción monástica, ejemplificada en uno de los textos más brillantes del mahāyāna, de gran influencia en Asia oriental: La enseñanza de Vimalakīrti (Vimalakīrtinirdeśa-sūtra), donde el laico Vimalakīrti, un bodhisattva versado en filosofía y en un estadio avanzado de su carrera, instruye a los monjes y, en algunos casos, se mofa de ellos (sobre todo de Śāriputra, representante de la vieja escuela de los sthavira). Este texto enfatiza la idea de que los grados más altos de santidad pueden alcanzarse fuera de la comunidad monástica, afirmación que sería disputada por la escuela theravāda de Ceilán. ${ }^{2}$ Según Lamotte el punto de inflexión se produce con el cisma de la escuela mahāsāmighika, que sustituye el viejo ideal de santidad (la obtención del nirvana, representado por el arhat) por el compromiso altruista del bodhisattva de permanecer en saṁsàra para aliviar los padecimientos de los que sufren. Ese quedarse en el saimsāra, esa permanencia se considera perpetua ya que los seres son incontables. Desde esta perspectiva, el que se encuentra en camino hacia el despertar, el bodhisattva, se considera superior al que ya lo ha logrado, el arhat. El propósito prevalece frente al objetivo. Los bodhisattva son los auténticos renunciantes: ellos no renuncian al mundo como los monjes, ellos renuncian al nirvana.

Esta versión de la historia encontraría una buena acogida entre los estudiosos japoneses de finales de siglo XX. Entre ellos destaca el estudio de Hirakawa sobre el culto a los túmulos relicarios (stūpa), monumentos que preservaban las reliquias del Buda histórico y que, al parecer, eran gestionados por laicos. ${ }^{3}$ Así, la devoción a las stūpa compitió con los rituales monásticos, creando una tradición religiosa alternativa centrada en la figura del bodhisattva, ser altruista comprometido con aspiraciones relativas a la vida cotidiana y a la costumbres del mundo.

\footnotetext{
${ }^{2}$ E. Lamotte, History of Indian Buddhism, from the Origins to the êka era, trad. Sara Boin-Webb, Louvain, Université du Louvain, 1988, p. 89.

3 A. Hirakawa, «The Rise of Mahāyāna Buddhism and its Relationships to the Worship of Stūpas», en Memoirs of the Research Department of the Toyo Bunko, Tokyo, 1963.
} 
Frente a la propuesta de Hirakawa, Gregory Schopen ha mostrado una serie de textos importantes del mahāyāna contrarios al culto de túmulos relicarios. ${ }^{4} \mathrm{La}$ tesis de Schopen es que los orígenes del mahāyāna no se organizan en torno al culto a las $s t \bar{u}$ $p a$, sino, desde dentro de la propia comunidad monástica, en torno al culto de ciertos textos. Así pues, un género literario, según esta segunda versión de la historia, es el responsable del surgimiento paulatino del mahāyāna. La idea es que el texto como objeto de culto, actitud ciertamente académica, es improbable que surgiera en ámbitos seculares. Esto nos hace suponer que dichos textos ya debían estar por escrito. Recordemos que el budismo fue desde sus orígenes una tradición oral, ${ }^{5}$ y es probable que pasaran de mano en mano, de modo más o menos confidencial, y fueran objeto de culto no sólo en sus usos como textos (se recitaban, se copiaban y se memorizaban) sino también como iconos: se les rendía culto con incienso, estandartes y campanillas. Esta liturgia confería a los monjes un gran mérito espiritual, mérito que, como veremos, se convertirá en objeto de la generosidad del bodhisattva, que puede transferirlo a otros seres para favorecer ciertas causas. En los primeros textos del mahāyāna, el mérito del culto al libro «se expresa siempre en términos de su comparativa superioridad con relación al que se deriva del culto a la stūpa o del culto a las reliquias». ${ }^{6}$ El Sūtra del Loto, por ejemplo, recomienda depositar escrituras budistas en las stüpa como equivalente de las reliquias corporales del Buda histórico. Si nos atenemos a los contenidos de estos textos, se hace más que evidente que los sūtra del mahāyāna fueron compuestos por monjes. Monjes cuyo entendimiento del dharma podía recoger aspiraciones de los laicos y que «usaron figuras de laicos para encarnar su crítica a otras concepciones del dharma que les resultaban excesivamente elitistas o conservadoras». ${ }^{7}$

La pregunta es entonces cuándo se produce ese cambio de perspectiva. Generalmente los estudiosos sitúan el origen del mahāyāna a principios de nuestra era. Para ello se sirven de una prueba, la más decisiva, de hecho la única, que no es india, sino china. Se trata de una colección de textos traducidos al chino por un tal Lokak·ema, que datan de finales del siglo segundo. Eso indicaría que los originales, supuestamente en sánscrito, fueron compuestos unos años antes. La pregunta es cuántos. Recientemente se han publicado algunos fragmentos breves del manuscrito Kushan de uno de los textos de esta colección: el Aștasāhasrikā Prajñāpāramitā (Discernimiento perfecto en ochenta mil líneas). Otro de los textos de Lokakșema es el Sukhāvatīvyūha Sütra, que tendría gran influencia en las tradiciones budistas de la Tierra pura de Asia oriental. Por sus contenidos parece evidente que los textos conocidos por Lokakṣema no pertenecen a las fases más antiguas del mahāyāna.

Pero un conjunto de textos no es un movimiento religioso. Si echamos un vistazo a los restos arqueológicos, especialmente numerosos en este periodo, no encontramos

${ }^{4}$ G. Schopen, «The Phrase "sa p"thivipradeśaś caityabhūto bhavet” in the Vajracchedikā: Notes on the Cult of the Book in Mahāyāna», IRJ 17 (1975), pp. 147-81.

${ }^{5}$ Hay quienes han sugerido que el surgimiento del mahāyāna se debe al uso de la escritura. Véase R. Gombrich, «How the Mahāyāna Began», JPBS 1 (1988), pp. 29-46.

${ }^{6}$ Schopen, op. cit., p. 169.

${ }^{7}$ P. Williams, Mahāyāna Buddhism. The Doctrinal Foundations, London, Routledge, 1989, p. 23 
en ellos referencias al mahāyāna o al buda Amitābha, ya sea en inscripciones o en relieves. Esto querría decir, según Schopen, que dejando de lado los textos y prestando atención a los restos arqueológicos, el mahāyāna sólo pudo tener cierto impacto en el culto budista indio a partir del siglo quinto. Ahora bien, si la Ratnāvalī, del que conservamos casi entero el original sánscrito, es un trabajo de Nāgārjuna (como así creo) y si aceptamos, de acuerdo a todas las pruebas, que Nāgārjuna vivió en torno al siglo segundo o tercero de nuestra era, entonces el mahāyāna como corriente de pensamiento dentro de la comunidad budista debió tener presencia en India mucho antes.

Sea como fuere, es claro que el mahāyāna nunca fue un fenómeno cohesionado, ni siquiera una escuela o secta. No es posible atribuirle un origen geográfico (aunque generalmente se asocia con el budismo del norte de India) y tampoco puede decirse que surgiera de manera repentina. Quizá se podría definir como una corriente de pensamiento que fue brotando gradualmente aquí y allá dentro de las diferentes escuelas y perfilándose en oposición, o como alternativa, a ciertas tendencias doctrinales. Lo que sí podemos afirmar es que dicha corriente de pensamiento estuvo asociada desde sus orígenes a la aparición de un nuevo género literario de tintes devocionales. No puede decirse que exista en él un elemento común, salvo su identificación como mahāyāna y su reivindicación frente a otras corrientes de pensamiento consideradas inferiores (hīnayāna). De hecho, el origen del término es polémico y se inscribe en una querella entre lo grande y superior $(m a h \bar{a})$ y lo mezquino e inferior (hīna), término que puede llegar a significar «basura».

A diferencia de la literatura canónica anterior, el nuevo corpus de textos carece de un código de reglas de conducta (vinaya), lo que indica que sus proponentes seguían códigos de escuelas no mahāyāna. El único vinaya completo que se conserva en su lengua original es el theravāda, redactado en pāli. Los seguidores del mahāyāna de Asia central y oriental, se regían por códigos sarvāstivāda y dharmaguptaka. Sabemos por los peregrinos chinos que recorrieron India en los primeros siglos de nuestra era que en los monasterios monjes mahāyāna y no mahāyāna compartían un mismo modus vivendi. Si aceptamos la tesis de Schopen, lo que parece razonable ya que las primeras inscripciones en piedra que contienen formulaciones mahāyāna son tardías, del siglo cuarto y quinto de nuestra era, ${ }^{8}$ podemos afirmar que en sus inicios el mahāyāna fue un movimiento minoritario al que pertenecían monjes y monjas de escuelas no mahāyāna, sin que se produjera un cisma o una ruptura en la comunidad budista.

Desplazamos ahora el punto de vista. Según la propia mitología del mahāyāna, al mismo tiempo que se celebraba en Rājāgṛha el primer concilio budista que recogería los textos que integrarían el canon, poco después de la muerte de Gautama Buda, hubo otro concilio paralelo de numerosos bodhisattva en el que se recitó la colección de textos del mahāyāna. Sin embargo, desde la perspectiva histórica sería equivocado considerar que pudo cerrase un canon en fecha tan temprana. No cabe duda de que muchos de los textos del canon de la escuela theravāda fueron compuestos varios siglos

\footnotetext{
${ }^{8}$ G. Schopen, «Mahāyāna in Indian Inscriptions» en Figments and Fragments of Mahāyāna Buddhism in India, Honolulu, University of Hawai'i Press, 2005, pp. 223-46.
} 
después de la muerte de Gautama Buda. Aunque posteriormente todas las escuelas reclamarían que su canon fue aquel que se recitó en el primer concilio, de cuya celebración no estamos seguros.

Lo que resulta indudable es que entre la muerte de Gautama Buda y el surgimiento del mahāyāna pasaron varios siglos en que se producirá, de forma gradual, un cambio de perspectiva que afectará sólo a una minoría dentro de una comunidad budista ya organizada. Hay que tener en cuenta que con anterioridad al emperador Aśoka (siglo III AEC), el budismo era un religión minoritaria en India. ${ }^{9}$ Apenas se encuentran restos arqueológicos budistas entre la muerte de Siddhārta, alrededor del 480 AEC y el reinado de Aśoka, que murió en el 232 AEC.

\section{EL DESARROLLO FILOSÓFICO DEL MAHĀYĀNA}

Según los textos de análisis doctrinal (abhidharma) no mahāyāna, lo que llamamos persona o individuo no constituye una realidad última (paramārtha). Se trata más bien de una realidad convencional (samvrti), un objeto verbal, un nombre sobreimpuesto a toda una serie de estados psicofísicos, transitorios y fugaces. Los constituyentes de dicha «persona» son cinco: el organismo físico (rüpa), las sensaciones (vedanā), las ideas (samjñā), las intenciones (samiskāra) y la percepción cognitiva (vijñāna). Ninguno de ellos por separado ni todos en su conjunto constituyen una realidad permanente sino que, surgiendo y desapareciendo a gran velocidad, estos factores se enlazan en continuidad formando una cadena que crea eso que convencionalmente llamamos individuo. Esa cadena no se interrumpe con la muerte sino que sus efectos se proyectan sobre sucesivos renacimientos guiados por la ley del «surgimiento condicionado».

Pues bien, para el abhidharma (sarvāstivāda y theravāda), lo que nos parece real no es sino la ilusión creada por estos factores que surgen y desaparecen de manera instantánea. De modo que lo único verdaderamente real en el mundo no son los mamíferos, los planetas o las plantas, sino precisamente estos elementos básicos que los constituyen y que se denominaban dharma. De ahí que se describiera el mundo mediante tres características fundamentales: impermanencia (anitya), insustancialidad (anātman) y decadencia (duhkha).

Siguiendo esta tendencia atomista (un atomismo que al mismo tiempo es físico y mental, material y espiritual), la tradición theravāda lista ochenta y dos «elementos fundamentales» (dharma), todos ellos condicionados, salvo uno, el nirvana. El sarvāstivāda lista setenta y cinco, de los cuales tres son incondicionados. Los dharma condicionados surgen y cesan instantáneamente, en un flujo continuo, y aunque su existencia es fugaz, a diferencia de los objetos que constituyen nuestra vida cotidiana, son reales y no meramente convencionales. Estos dharma, de acuerdo al sarvāstivāda, son sustancias (dravya) que tiene existencia propia (svabhāva).

\footnotetext{
${ }^{9}$ A. L. Basham, «Aśoka and Buddhism: a reexamination», JIABS 5/1 (1982), p. 140.
} 
El theravāda subdivide su lista en tres grupos. El primer grupo incluye los dhar$m a$ físicos (28), que incluyen los cuatro elementos: fuego, aire, tierra y agua, la agilidad, la maleabilidad, la elasticidad, lo nutritivo, etc. El segundo, los dharma mentales (52), veinticinco moralmente positivos: ausencia de codicia, ausencia de resentimiento, fe, atención, empatía, generosidad, etc. Catorce negativos, que incluyen el odio, el resentimiento, la codicia y las opiniones erróneas. Y trece moralmente neutros que adquirirán una textura moral en función de los dharma con los qué interaccionen. Los primeros siete de estos trece son comunes a toda actividad mental: percepción, sensación, contacto, concentración, atención, etc. El tercero lo compone el dharma de la conciencia (vijñanna), el último de los elementos condicionados, que como todos los demás dharma surge, dura un instante y es reemplazando por otro del mismo tipo. Estamos pues ante lo que podría llamarse un atomismo que es al mismo tiempo material y espiritual.

El objetivo de la meditación consistirá en descomponer la experiencia en estos factores fundamentales que constituyen la única y fugaz realidad. Acabar con la ignorancia que arrastra el devenir es precisamente ver las cosas en función de lo único real que hay en ellas, los dharma. Cesando esta ceguera, cesa el apego por las cosas y el arhat encuentra acceso al nirvana.

Esta visión escolástica es posteriormente sometida a crítica por el madhyamaka, la primera de las escuelas filosóficas del mahāyāna. Nāgārjuna expone en ella la vacuidad de los dharma, su falta de realidad y naturaleza intrínseca. Esta crítica ya se anunciaba en algunos textos de las dieciocho escuelas, como en el Lokānuvartana de los mahasamghika y, respecto a las opiniones o creencias (drșțî), en algunos de los libros más antiguos del canon pāli: como el Atțhakavagga del Suttanipāāta. ${ }^{10}$

¿Dónde encontrar pues esa realidad que no sea meramente convencional? El Mahāvastu, un texto de transición entre la literatura no mahāyāna y la mahāyāna, narra la leyenda de Siddhārtha Gautama e incorpora numerosas jātaka y avadāna (historias en sí mismas), como episodios pseudo biográficos de las vidas anteriores de Śākyamuni. En su introducción, el narrador asocia la obra a la escuela lokottaravāda, una subescuela del mahāsāmghika. ${ }^{11}$ Subyace a toda la obra la idea de un Buda supramundano cuyo nacimiento, vida y muerte no parecen ya pertenecer al ámbito de la hu-

\footnotetext{
${ }^{10}$ L. Ó. Gómez ha explorado los paralelismos entre este texto y el mādhyamaka de Nāgārjuna, fundamentalmente en relación a la ausencia de opiniones o puntos de vista. En el Atțakavagga, la raíz del sufrimiento y el devenir se descubre en la tendencia de la mente a agarrarse apasionadamente a sus propias fantasías, a sus prolíficas conceptualizaciones: «Proto-Mādhyamika in the Pāli Canon?», PEW 26/2 (1976), pp. 137-165.

${ }^{11}$ El Mahāvastu coincide con el Nidānakathā en disponer la vida del buda en tres secciones. La primera se inicia en tiempos del buda Dīpamkara y narra sus vidas previas. La segunda sección se ocupa de la estancia en el paraíso Tușita, donde el bodhisattva decide renacer en el vientre de la reina Māyā, el milagro de su nacimiento, su escapada de palacio, su batalla por el despertar y su victoria sobre Māra bajo el árbol de Gayā. La tercera se ocupa de las primeras conversiones, la creación de la comunidad monástica y la difusión de la doctrina. A pesar de la estructura mencionada, Moriz Winternitz (History of Indian Literature, Vol. II, Munshiram Manoharlal Plublishers, Delhi, 1991, p. 240) sugiere que el Mahāvastu «puede verse como un laberinto, en el cual el hilo de la narración de la vida de buda será descubierto sólo con dificultad, pues la narración misma se ve continuamente interrumpida por otros asuntos, como las jātaka, avadāna y episodios doctrinales. No parece haber un principio de ordenamiento de los materiales y a menudo faltan transiciones de un episodio a otro».
} 
mana contingencia y necesidad. Y empieza a concebirse esa vida como el episodio culminante de un antiguo destino. El Buda histórico, ese hombre que recorrió las estribaciones del Ganges, los reinos de Maghāda, Kāśî y Kośala, que respiraba, comía y dormía como cualquier otro hombre, comienza a concebirse como un fenómeno aparente. Llevado por su identificación afectiva con los seres que sufren, el Buda aparece en este mundo. Y cuando el Buda parece dormir, medita, cuando sonríe ilumina las mentes, cuando parece hablar de lo cotidiano, habla en verdad de lo eterno.

El carácter supramundano del Buda abre aparentemente el determinismo estricto del karma, que pasa de ser una ley rígida de retribución de los propios actos (del esfuerzo individual en la conducta mental y verbal), a albergar conceptos que socavan esa individualidad. Entre ellos encontramos el concepto hindú de prasāda (asociado con las concepciones occidentales de gracia) y el concepto de dedicación o transferencia de mérito (punyya pariṇāmanā). Es aquí donde la vía de la devoción encuentra sus efectos, que se incorporan sin obstáculos a la doctrina del karma entendida no ya como una causalidad limitada únicamente al «yo» sino que adquiere un carácter colectivo en consonancia con la aspiración del bodhisattva de rescatar a los seres del sufrimiento. El propósito de despertar reemplaza al logro mismo del despertar. La potencia sustituye al acto.

Queda por resolver la cuestión de la procedencia y legitimidad de dicha innovación. Los propios sūtra de la prajñāparamitā se defienden de las acusaciones de apócrifos. Lo que en ellos se expone, dicen sus detractores, no es la «palabra de Buda» (buddhavacana) sino la lírica, inspirada en la tradición, de ciertos poetas. Según el mahāyāna, esta acusación procede de Māra, el maligno. Sin embargo, desde la perspectiva histórica no deberíamos aceptar sin matizaciones la afirmación sectaria de que todos los sūtra de las tradiciones no mahāyāna fueron pronunciados por el propio Buda. Generalmente los requisitos para que un texto fuera considerado buddhavacana fueron o bien que el propio Buda aprobara lo que se decía en él, o bien que el Buda mismo invitara a otra persona a predicar en su nombre. Ambas condiciones requerían la presencia de Gautama Buda en este mundo. Sin embargo, la mayoría de los seguidores del mahāyāna consideran que sus textos fueron predicados por Śākyamuni, e invariablemente se inician con la frase de Ānanda: «Así escuché en cierta ocasión...» especificando a continuación el lugar geográfico en el que tuvo lugar la enseñanza. Sin embargo, las pruebas históricas de las que disponemos contradicen ambos supuestos, aunque esto no quiera decir que los sūtra del mahāyāna no contengan enseñanzas que pudieran remontarse a la época de Gautama Buda.

Dentro de la propia tradición mahāyāna se desarrolla también otra genealogía de los textos, asociándolos no con el Buda histórico, que murió en el siglo quinto o cuarto antes de nuestra era, sino con la experiencia inspirada por los numerosos budas que, en el momento de la composición del texto, existían en otros planos de realidad. Esa enseñanza se vuelve accesible mediante ciertos estados de la mente concentrada que permiten, por ejemplo, la visualización y audición de la enseñanza que lleva a cabo Amithāba en la «tierra pura» de Sukkhāvatī. Śāntideva en su Śikṣasamuсcаya establece cuatro condiciones de aceptación de esas enseñanzas inspiradas. 
Su conformidad a la verdad, su conformidad con el dharma, su electo purificador (en el sentido de producir una disminución de las kleśa), y su capacidad de evocar los aspectos positivos del nirvana. Se admite así un origen revelado (a veces visionario) de esta literatura. Pero no sería exacto decir que esta apertura respecto a la palabra de Buda sea exclusiva del mahāyāna. También en el canon pali encontramos la idea de que «lo que está bien dicho es palabra de Buda» (Uttaravipatti sutta), mientras que en otros textos asocian con el dharma todo aquello que conduce a la liberación del espíritu.

El voto del bodhisattva es el eje alrededor del cual gira la devoción en el mahāyāna. El Lalitavistara, una leyenda de Gautama Buda asociada a la escuela sarvāstivāda, describe los cuatro votos realizados por Śākyamuni. Esta promesa aparece también en el Abhidharmakośa de Vasubandhu. «Ay, ante este mundo ciego, sin ojos para ver, que aparezca yo [en el futuro] como un despierto, como protector de los desvalidos». Otro texto, el Diálogo del diamante, quizá uno de los más representativos del mahāyāna, complementa de manera enigmática la tarea del bodhisattva. ${ }^{12}$

El bodhisattva debería pensar de este modo: todos los seres del universo, ya nazcan de un huevo o de una matriz, de la humedad o milagrosamente, con forma o sin forma, con percepción o sin ella, a todos ellos conduciré al ámbito del nirvana. Y aunque incontables seres hayan sido llevados al nirvana, de hecho ningún ser ha sido conducido al nirvana. ¿Por qué? Porque si en el bodhisattva concibiera la noción de un «ser», no podría ser llamado «ser del despertar» (bodhi-sattva). Y ipor qué? Porque no debe llamarse «ser del despertar» a aquel que concibe la idea de un «yo» o de un «ser» o de una «persona».

Cuando se habla del voto del bodhisattva con frecuencia se pasan por alto sus aspectos taumatúrgicos. El voto, como tantos otros gestos del compromiso religioso y tantos otros estados interiores de la voluntad devota, concede al que lo pronuncia poderes especiales. No sólo es un modelo ético y un ideal abstracto de santidad, sino que también es un manantial de prodigios que repercuten en el bodhisattva que lo pronuncia y en los seres vivos que serán objeto de su rescate.

La transición a una definición del voto caracterizada por la identificación afectiva con los seres que sufren, que se vislumbra ya en la cita anterior, se hace más explícita en el Mahāvastu. En el volumen primero de esta obra Megha pronuncia el voto ante el buda del pasado Dīpamkara y resume los elementos fundamentales de la aspiración del bodhisattva.

Que sea yo también en una vida futura un Tatăghata, arhat, un buda perfecto [...]. Que una vez haya cruzado a la otra orilla, ayude al prójimo en esa misma travesía. Que una vez liberado pueda liberar a los demás. Que una vez consolado

\footnotetext{
${ }^{12}$ Sigo la traducción de E. Conze (ed./trad.), Vajracchedika Prajnaparamita, Serie orientale Roma; 13, Is. M.E.O., 1957.
} 
pueda consolar a los demás, como hizo hoy Dīpamikara. Que logre todo esto para beneficio de la humanidad, por la cercanía que siento hacia el mundo, para bien de las grandes multitudes, para ventura de los seres celestiales y de los hombres.

Como preparación para la consecución del despertar o como su intención motriz, el voto se asocia aquí a la predestinación (vyākaraṇa), pues los votos se toman, según el mito, ante un buda del pasado, es decir, en una vida anterior, en una época remota, cuando vivía en el mundo un buda perfecto y completo. Y es ese buda el que reconoce la validez del voto y garantiza sus efectos al tiempo que predice que la persona que lo toma alcanzará la condición de despierto.

Los votos que pronunció Śākyamuni en el pasado, se mencionan también en un texto pāli postcanónico: la introducción a los jātaka (Nidānakathā), de nuevo en el contexto del encuentro con Dīpamkara. Si bien es cierto que algunos de los ejemplos citados son contemporáneos al surgimiento del mahāyāna (por ejemplo el de Vasubandhu), también lo es que expresan doctrinas comunes a muchos de los nikāya que surgieron antes del mahāyāna y se desarrollaron en paralelo a esa tradición de pensamiento.

El general, los textos recomiendan que se hagan los votos ante los budas del universo, o ante una imagen de uno o múltiples budas, o ante algún maestro amigo de la virtud. El Dharma-saingraha distingue tres tipos de voto: el que garantiza el éxito en la búsqueda del despertar del propio bodhisattva, el que asegura la consecución de los deseos de todos los seres vivos; y el que hace posible la purificación del mundo que sirve de tierra del despertar para el bodhisattva (buddhakșetra-pariśodhaka). Este tercer tipo apunta a una concepción clave del mahāyāna: los budas manifiestan su poder salvífico purificando mundos, pues todo bodhisattva desea crear su propio campo de acción, convirtiendo un mundo impuro y desagradable en un paraíso hermoso y purificado.

El voto no sería posible sin otra de las nociones clave del mahāyāna: el «espíritu del despertar» (bodhi-citta). Este compuesto sánscrito significa tanto la resolución de buscar el despertar, como la mente que se encuentra potencial o inmanentemente despierta. La idea, como casi todas las ideas del mahāyāna, aparece ya en fuentes no mahāyāna, como en el Abhidharma-dīpa y en textos de transición como el Mahāvas$t u$, aunque será en la tradición mahāyāna donde adquiera toda su relevancia doctrinal. Bodhicitta representará en ella el instinto de empatía y el cultivo de la identificación afectiva con los seres que sufren, siendo el fundamento del compromiso del bodhisattva con el saimsāra, sintetizando aspectos clave de la intencionalidad, tanto hacia los demás como hacia el propio yo, y dirigiendo su conducta transformadora.

El «espíritu del despertar» presenta diferentes niveles de significado. La resolución de lograr el despertar puede entenderse como un estado de la mente (un proceso mental) o como una promesa solemne (el voto como acto verbal) que se encarna y expresa en ciertas pronunciaciones, actos y gestos rituales (como dedicación del mérito o el recitado público de los votos). Así, bodhicitta no es sólo el sentimiento que inspira la carrera espiritual (caryā) del bodhisattva, su resolución inicial, sino también el 
impulso que la mueve y hace avanzar. En este segundo aspecto, como fuerza motriz, mantiene la perseverancia en el camino, y representa tanto el deseo de lograr el objetivo como el despertar mismo, dando paso a la idea de un «despertar innato» que comentaremos más adelante.

La mayoría de las tradiciones mahāyāna considera el pensamiento inicial en el despertar el momento más importante de la carrera del bodhisattva. La irrupción de esa idea, la aspiración al bien y el hecho raro y primoroso que ella encierra constituirán el impulso de dicha carrera. Se trata de un instante sagrado, público y privado al mismo tiempo. Un episodio mental que va acompañado de un ritual público. Conviene recordar de nuevo que en general se entiende que la expresión ritual del voto y la adopción de los preceptos del bodhisattva en presencia del tutor espiritual (kalyānamitra), o ante los budas del universo, es garantía de que antes o después sobrevendrá el despertar. Algunos autores como Śāntideva conciben el bodhicitta como una fuerza de tal potencia que se diría externa a la voluntad, el esfuerzo o la atención del individuo que lo concibe. Para Śāntideva, una vez la persona ha hecho surgir la resolución, el bodhicitta es como el despertar mismo, presente de forma manifiesta o latente en todos sus procesos mentales y corporales.

Se puede hablar de un proceso histórico en el que la noción abstracta o la realidad psicológica de la resolución acaba por convertirse en una fuerza espiritual autónoma. Los textos del mahāyāna glorifican al bodhicitta como el sine qua non de la práctica y la esencia del despertar, como un tesoro escondido, una panacea o una hierba medicinal (por ejemplo, en el Maitreya-vimokșa del Gandavyūha-sūtra). Sin embargo, dicha celebración hiperbólica del bodhicitta con el tiempo tomaría la forma de una reificación de dicho estado mental. El bodhicitta se encuentra presente incluso si uno carece de toda virtud, como una joya escondida bajo un montón de excremento. Aquel que hace surgir el pensamiento del despertar será venerado por los dioses y los hombres. Y, según la metáfora del Dalai Lama, el pensamiento del despertar es como el brillo del relámpago en la noche oscura de la ignorancia humana. Y aún más, ese pensamiento del despertar otorga un poder especial al que lo concibe y lo protege de todo peligro y desventura.

Se hilvanan así liturgia, teoría y ética. El concepto es tan importante en el mahāyāna como la dedicación del mérito (punya-pranidhāna) y ha servido de elemento de cohesión de las distintas tendencias rituales y sociales de la tradición, enlazando la idiosincrasia ritual y doctrinal con una realidad eterna, inefable y liberadora donde las diferencias se disuelven. Teológicamente, bodhicitta puede considerarse un equivalente del concepto hindú de prasāda y la concepción occidental de gracia: bodhicitta simboliza el misterio de la presencia sagrada en los seres imperfectos que necesita tanto la liberación como imaginarla.

Encontramos ecos de dichas concepciones en la llamada doctrina del embrión del Tathāgata (Tathāgata-garbha), para la que el nirvana del Buda se encuentra ya presente en cada ser vivo. Esa esencia que mora en todos los seres y que es pura potencia, constituye un estado permanente de dicha (como el de los budas) y se encuentra libre del yo y de las cualidades negativas de la yoidad (de modo que ese embrión se- 
ría lo opuesto a lo efímero, lo insustancial y lo doloroso, las tres marcas de lo existente, según las concepciones clásicas).

Estas ideas darán lugar, en el Japón medieval, a la doctrina del «despertar original» (hongaku), que prevaleció en la escuela tendai en el siglo XI. Esta doctrina mantiene que el despertar no es un objetivo a lograr ni una potencia a actualizar sino la auténtica naturaleza de todas las cosas, ya sea grillos, árboles o seres humanos. Desde esta perspectiva, lo cotidiano (comer, dormir e incluso fantasear) forma parte de la conducta de un Buda. Se ha descrito esta doctrina como el ápice de las filosofías mahāyāna de la no dualidad, iniciadas por el filósofo indio Nāgārjuna en torno al siglo segundo. Al ser las cosas vacías, al carecer de naturaleza propia, se implican unas a otras, se necesitan y complementan, se requieren y llaman. Así, todos los fenómenos, ya sean formas o colores, sonidos o aromas se consideran la actividad de un Buda cósmico que impregna el universo en su totalidad. Así, los todos los dharma son buddhadharma, todas las aflicciones despertar, todo samisāra nirvana. El círculo se ha cerrado.

\section{CONCLUSIONES}

Recapitulemos: a principios de nuestra era se inicia en el budismo indio un género literario dentro de la propia comunidad monástica. Esta nueva literatura, que se reivindica como «palabra de Buda», resalta la figura del bodhisattva (aquel que se encuentra en el camino hacia el despertar para beneficio de todos los seres vivos) como ideal supremo. En el siglo II o III, Nāgārjuna equipara lo fugaz y lo permanente, saímsāra y nirvana, elevando esta literatura, en gran parte devocional, a rango filosófico. Nirvana y samisāra pasan a ser idénticos referentes de experiencias dispares, y su distinción se establece en el modo de estar y percibir el mundo. Este paso tiene como consecuencia que para ciertas tradiciones budistas, identificadas como mahāyāna, el nirvana deja de ser el lugar central para dar paso a una determinada actitud filosófica (el discernimiento de la vacuidad), y una determinada actitud altruista: la identificación afectiva y la solidaridad con aquellos que sufren.

Es muy probable que esta nueva tendencia surgiera aquí y allá sin que existiera una comunicación estrecha entre sus seguidores. Por lo que podemos colegir de la historia, este giro se produce en minorías desperdigadas a lo largo de la geografía india. Algunos grupos de monjes y monjas, así como ciertas comunidades laicas, abrazaron, protegieron y difundieron esta nueva literatura, donde el culto y la devoción se extenderían a los propios manuscritos. Dejando al margen la posibilidad de que algunos de sus seguidores experimentaran, mediante sueños o mediante el ejercicio de la meditación, el contacto directo con el Buda, lo cierto es que consideraron que la misma doctrina, encarnada en el texto, engarzada mediante palabras sagradas, constituía el auténtico cuerpo de Buda (dharmakāya), cuya realidad sobrepasaba la del cuerpo psicofísico del Buda histórico que al que se rendía culto en los túmulos relicarios (stūpa).

Lo histórico, como suele suceder en India, se diluye para dar paso a narrativas que inspiran una forma de vida y sirven como modelo a métodos para erradicar la igno- 
rancia y el sufrimiento. Apelar al Buda histórico supone, desde esta nueva perspectiva, recurrir a factores contingentes que, aunque indisociables de la vida humana (o precisamente por ello) pasan a ocupar un lugar inferior en la imaginación de los budistas, que recrean la presencia de Buda no ya como testigos, sino en un ámbito que trasciende y al mismo tiempo acompaña la experiencia de la vida. 